\title{
Modeling Frequency of Using Informal Public Transport and Public Bus: A Case Study in Phnom Penh, Cambodia
}

\author{
Nguonsong Eung ${ }^{\mathrm{a}}$ and Kasem Choocharukul ${ }^{\mathrm{b}, *}$ \\ Department of Civil Engineering, Faculty of Engineering, Chulalongkorn University, 254 Phaya Thai Road, \\ Pathumwan, Bangkok 10330, Thailand \\ E-mail: anguonsong72@gmail.com, bkasem.choo@chula.ac.th (Corresponding author)
}

\begin{abstract}
For decades, informal transport modes such as Motodup and Remork can be commonly observed in the urban area of Phnom Penh. They play an important role as a major public transport for local travelers, even before the public bus was put into full operation in 2014. This study aims to investigate underlying factors that influence the frequency of using informal transport and public bus by considering traveler's socioeconomic variables, trip characteristics, and operational characteristics of each transport mode. Utilizing ordered probabilistic modeling, data is analyzed based on 483 samples collected from four main areas in Phnom Penh, i.e., CBD, educational, residential and suburb areas. Results indicate that students do not use Motodup frequently, but they would prefer Remork. Moreover, travel cost is seen to be the major factor that could reduce the likelihood of using Motodup and public bus; however, this variable is not found significant in determining the frequency of using Remork. In terms of commuters' attitudes, Remork and public bus passengers perceive comfort and availability importantly. The more important they value these two factors, the more frequent they would use such modes. Since the public bus is currently a highly promoted public transport, policy makers should incorporate the quality of comfort and availability, and should keep the bus fare low in order to increase the usage frequency.
\end{abstract}

Keywords: Informal transport, public bus, Phnom Penh, ordered probit model.

ENGINEERING JOURNAL Volume 22 Issue 3

Received 3 October 2017

Accepted 18 February 2018

Published 28 June 2018

Online at http://www.engj.org/

DOI:10.4186/ej.2018.22.3.109 


\section{Introduction}

Informal transport is commonly seen in many cities of developing countries. There are various kinds of informal transport, including motorized and non-motorized modes [1]. Their characteristics are different by vehicle fleets, and thus no overall definition of informal transport can be given. Instead, informal transport is simply referred to travel modes directly. Although a mass transit system is generally considered an effective mode to relieve traffic congestion in urban area, accessibility of passengers from their origin to transit stations relies mostly on informal transport, which takes a role as a feeder in transport system [2]. In some cases, informal transport could be regarded as the main public transport in urban area that provides passengers with a door-to-door service.

In Phnom Penh, the capital city of Cambodia, informal transport has been operated extensively across the city long before the official launch of city buses in 2014. Although the public bus can be considered a competing mode, many passengers still prefer local informal transport for its convenience, availability and door-to-door services. There are many kinds of informal transport modes available in Phnom Penh, but the most common ones are motorcycle taxis and motorcycle rickshaws, commonly known as Motodup and Remork (See Fig. 1). The operation of these two modes are quite similar, i.e. they operate on non-fixed routes with non-fixed price. In addition, the fare is completely negotiable, which is mainly based on travel distance, time of the day (e.g. peak/off-peak hour, day/night time) and the capacity it can accommodate. Remork normally charges higher due to vehicle's larger capacity.

Informal transport can be often seen at high-demand places such as markets, hospitals and airport. Since the market condition is quite competitive, drivers can basically wave for passengers instead of passengers going for them. Previous study showed that the number of Motodups have declined lately, while the number of Remork fleet have increased to roughly 6,000 in 2012 [3]. The public bus, on the other hand, has been operated by the municipality of Phnom Penh. A total of 45 buses are currently in operation along three lines covering a total distance of $19 \mathrm{~km}, 19 \mathrm{~km}$, and $13.5 \mathrm{~km}$ for line 1 , line 2 and line 3 , respectively [4]. The operation for all routes starts from 5:00 a.m. to 8:30 p.m. with a fixed fare of 1500 KHR (roughly 0.37 USD). To our knowledge, no record of person trip survey has been conducted by official government that the number of modal share remain unknown. However, some studies has reported that number of Motodup has declined from 19\% to 8\%, while Remork has increased from 6\% to 9\% between 2001 and 2011 [3]. As of 2012, Remork fleets has increased to roughly 6,000 vehicles [3].

Most informal transport drivers work together under several associations in a form of informal sector [3]. Public bus provides passengers with lower fare and better safety; however, its service quality remains relatively low, leading to a long travel time [4]. This situation could be implied that an effective public transportation has yet to be found in the city. To adequately regulate the usage of Motodup, Remork and public bus, it is necessary to understand the characteristics of passengers, and underlying factors that could influence the frequency of using those modes. Findings would lead to an effective policy implementation in order for the city to provide a good integration between public bus and conventional informal transport modes. The present study examines the behavior of passengers in Phnom Penh and applies ordered probabilistic models to investigate significant factors influencing frequency of using public transport modes.

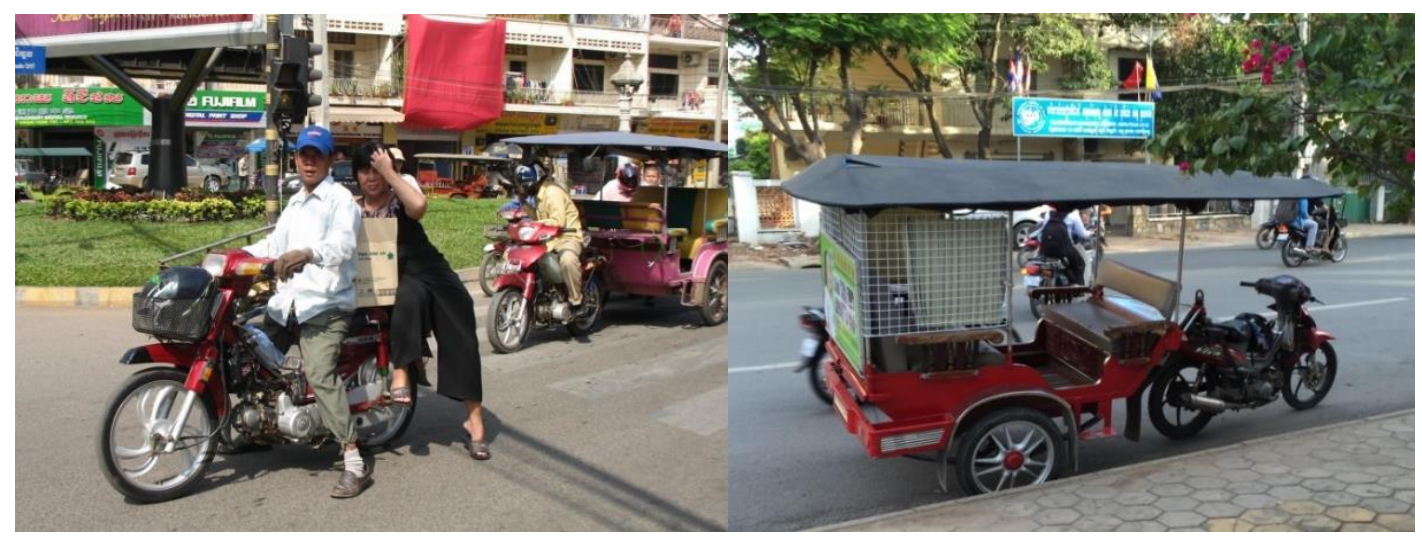

(a) Motodup

(b) Remork

Fig. 1. Common informal transport in Phnom Penh. 


\section{Literature Reviews}

\subsection{Definition of "Informal Transport"}

From literature, a specific definition of informal transport remains unclear. Informal transport is also known as "paratransit", "low-cost transport", "intermediate technologies" or "third-world transport" [5]. For some specific modes, however, these terms may not be true. In Asian developing countries, certain informal transport modes (e.g. motorcycle taxi, and Remork) charges a more expensive fare than public bus does. Moreover, it is typical to see informal transport serving local passengers in many Asian cities, especially at high-demand places, including local markets and residential areas. Later studies have proposed a new term LAMAT to describe informal transport specifically for Asian developing countries, which stands for "Locally", "Adapted", "Modified" and "Advance Transport" [1]. Travel modes that can be categorized as LAMAT can be intermediate transport, traditional mass transit, non-motorized vehicles (e.g. Rickshaw), and four-wheel vehicles (i.e. minibus, Songtaew, Silor Lek) that can accommodate up to 25 seats [1]. Apart from developing countries, informal transport or paratransit means completely different in the United States. Specifically, this term is referred to a door-to-door transport service for senior citizens and disabled passengers [6]. Since the characteristics of informal transport are different across the globe, it is advised to refer to each mode individually. For instance, we may point out Motodup or Remork for Cambodia, Songtaew or Silor Lek for Thailand, Rickshaw for Bangladesh, Angkot for Indonesia, and Jeepney for the Philippines.

\subsection{Past Studies of Informal Transport}

Informal transport plays an important role in urban transport system of several developing countries. Such a system has connected deeply with mobility of urban citizens, especially for those who do not have direct access to formal public transport. In some cases, services of informal transport are also regarded as an important source of income for urban poor communities, who mostly lack of skills [7]. From extant literature, various studies attempted to observe the characteristics and role of informal transport. They can be summarized in Table 1.

Table 1. Past studies of informal transport in Asian cities.

\begin{tabular}{|c|c|c|c|c|}
\hline Study & Year & $\begin{array}{l}\text { Study } \\
\text { Location }\end{array}$ & Study Objectives & Key Results \\
\hline $\begin{array}{l}\text { Etherington and } \\
\text { Simon [8] }\end{array}$ & 1996 & $\begin{array}{l}\text { Phnom Penh, } \\
\text { Cambodia }\end{array}$ & $\begin{array}{l}\text { provided an analysis of a popular } \\
\text { non-motorized informal } \\
\text { transport, known as Cyclo and } \\
\text { the employment conditions of } \\
\text { the riders }\end{array}$ & $\begin{array}{l}\text { The study found the inequality in } \\
\text { terms of earning opportunity among } \\
\text { Cyclo rider who resides in Phnom } \\
\text { Penh and migrants from provinces. } \\
\text { Either renting or owning the vehicle, } \\
\text { migrant riders tend to work longer } \\
\text { hour with less income since they have } \\
\text { to pay for organization in return of } \\
\text { support to access in urban } \\
\text { environment. }\end{array}$ \\
\hline $\begin{array}{l}\text { Joewono and } \\
\text { Kubota [9] \& [6] }\end{array}$ & $\begin{array}{l}2005 \& \\
2007\end{array}$ & $\begin{array}{l}\text { Bandung, } \\
\text { Indonesia }\end{array}$ & $\begin{array}{l}\text { investigated the characteristics } \\
\text { of Angkot and the level } \\
\text { satisfaction of passenger toward } \\
\text { the service in Bandung }\end{array}$ & $\begin{array}{l}\text { Informal transport still exists in many } \\
\text { cities of Indonesia and it is still } \\
\text { accepted by community. The result } \\
\text { indicates that users are not satisfied } \\
\text { with current service. However, loyal } \\
\text { passengers are still found. }\end{array}$ \\
\hline Loo [10] & 2007 & $\begin{array}{l}\text { Hong Kong, } \\
\text { China }\end{array}$ & $\begin{array}{l}\text { explored the role of residents' } \\
\text { coach in Hong Kong, while } \\
\text { mass rapid system has been } \\
\text { developed extensively across the } \\
\text { city }\end{array}$ & $\begin{array}{l}\text { The analysis suggests that the } \\
\text { integration between residents' coach } \\
\text { and public transport system should be } \\
\text { implemented, since residents' coach } \\
\text { has filled the gap of transport system } \\
\text { in urban area. }\end{array}$ \\
\hline $\begin{array}{l}\text { Tangphaisankun et } \\
\text { al. [2] }\end{array}$ & 2009 & $\begin{array}{l}\text { Bangkok, } \\
\text { Thailand }\end{array}$ & $\begin{array}{l}\text { conducted a study focusing on } \\
\text { the impact of commuters toward } \\
\text { informal transport functioning } \\
\text { as a feeder to mass transit system }\end{array}$ & $\begin{array}{l}\text { Commuters have positive influence on } \\
\text { connection between informal } \\
\text { transport and mass transit system that } \\
\text { leads to the future use of both modes. }\end{array}$ \\
\hline
\end{tabular}




\begin{tabular}{|c|c|c|c|c|}
\hline Study & Year & $\begin{array}{l}\text { Study } \\
\text { Location }\end{array}$ & Study Objectives & Key Results \\
\hline $\begin{array}{l}\text { Choocharukul and } \\
\text { Sriroongvikrai [11] }\end{array}$ & 2011 & $\begin{array}{l}\text { Bangkok, } \\
\text { Thailand }\end{array}$ & $\begin{array}{l}\text { conducted an analysis of } \\
\text { characteristics of small-sized } \\
\text { converted pickup truck (Silor } \\
\text { Lek) in Bangkok and compared } \\
\text { such mode with other common } \\
\text { informal modes such as } \\
\text { Songtaew and motorcycle taxi }\end{array}$ & $\begin{array}{l}\text { From supply side, Silor Lek is one of } \\
\text { the major informal transport in } \\
\text { Bangkok, which has market } \\
\text { competition with other informal } \\
\text { modes. Some illegal operations, and } \\
\text { risky driving behavior are observed. } \\
\text { Study suggests to consider Silor Lek as } \\
\text { a complimentary mode to formal } \\
\text { transport. }\end{array}$ \\
\hline $\begin{array}{l}\text { Hossain and Susilo } \\
\text { [12] }\end{array}$ & 2011 & $\begin{array}{l}\text { Dhaka, } \\
\text { Bangladesh }\end{array}$ & $\begin{array}{l}\text { addressed the usage of rickshaw } \\
\text { and its social impact, while this } \\
\text { mode was blamed to be the } \\
\text { cause of congestion and was } \\
\text { prohibited on some major roads }\end{array}$ & $\begin{array}{l}\text { Rickshaw roles importantly in } \\
\text { transport system of Dhaka. Absence, } \\
\text { of rickshaw would shift passengers' } \\
\text { mode choice to auto-rickshaw or } \\
\text { taxicab rather than formal public } \\
\text { transport such as bus. }\end{array}$ \\
\hline $\begin{array}{l}\text { Tuan and Mateo- } \\
\text { Babiano [13] }\end{array}$ & 2013 & $\begin{array}{l}\text { Ho Chi Minh, } \\
\text { Vietnam }\end{array}$ & $\begin{array}{l}\text { investigated the service } \\
\text { characteristics of motorcycle } \\
\text { taxi in Ho Chi Minh city, } \\
\text { explored its impact and analyzed } \\
\text { its potential for future urban } \\
\text { transport system }\end{array}$ & $\begin{array}{l}\text { The analysis foresees that motorcycle } \\
\text { taxi will keep growing and plays an } \\
\text { important role in supporting formal } \\
\text { transport system. The study also } \\
\text { suggests the application of meter } \\
\text { technology in order to improve service } \\
\text { of motorcycle taxi in terms of fare } \\
\text { setting. }\end{array}$ \\
\hline Phun et al. [3] & 2015 & $\begin{array}{l}\text { Phnom Penh, } \\
\text { Cambodia }\end{array}$ & $\begin{array}{l}\text { investigated the operational and } \\
\text { fare characteristics of Motodup } \\
\text { and Remork in Phnom Penh }\end{array}$ & $\begin{array}{l}\text { Fare of Motodup and Remork was } \\
\text { influenced by some factors including } \\
\text { trip characteristics and driver working } \\
\text { condition. }\end{array}$ \\
\hline
\end{tabular}

The studies of informal transport are worth exploring since the insight characteristics can be better understood, leading to an appropriate and efficient integration between the conventional transport and the developed ones. From literature, understanding unique characteristics of informal transport in Asian developing countries is quite essential, since the differences among their operational characteristics serve a vital knowledge that informal transport can be realized in a wider scale and from different perspectives. Nevertheless, such a study in Cambodia is not yet sufficient at present, and thus more researches are required. To shed more light from past studies, another view from passengers' side should also be considered. In particular, underlying factors that could potentially influence the frequency of using informal transport currently remain unknown. This study will take this aspect into account.

\section{Methodology}

\subsection{Sample and Survey Questionnaires}

Respondents are randomly selected from passengers in Phnom Penh. A total sample size of 600 was collected from four main areas, covering Central Business District (CBD), educational, residential and suburb areas (See Fig. 2). The survey questionnaire consists of three main sections - passengers' socioeconomic data, trip characteristics, and passengers' perception on the operation of Motodup, Remork and public bus. The first section asks passengers' socioeconomic information such as gender, age, education background, income, residential area, and vehicle occupancy. In the second part, travel behavior of passengers is solicited for all three modes. Such variables include trip frequency, travel time, trip objective, and travel cost. The last section consists of attitudinal statements regarding each travel mode. They were presented in a five-point Likert scale. The questionnaire was first written in English and later translated into Khmer language. Doubled translated technique was applied to ensure the accuracy between two languages.

\subsection{Data Collection}

Data collection was conducted in Phnom Penh during December 7-10, 2015 with the assistance of six surveyors. Based on a face-to-face interview survey, a total of 600 questionnaires were collected in four areas. Respondents were targeted to be general travelers who have experienced using either Motodup, Remork, or 
public bus. The survey was conducted on both weekday and weekend to take into account different trip purposes. After cleaning the data, a total of 483 samples could be used for analysis.

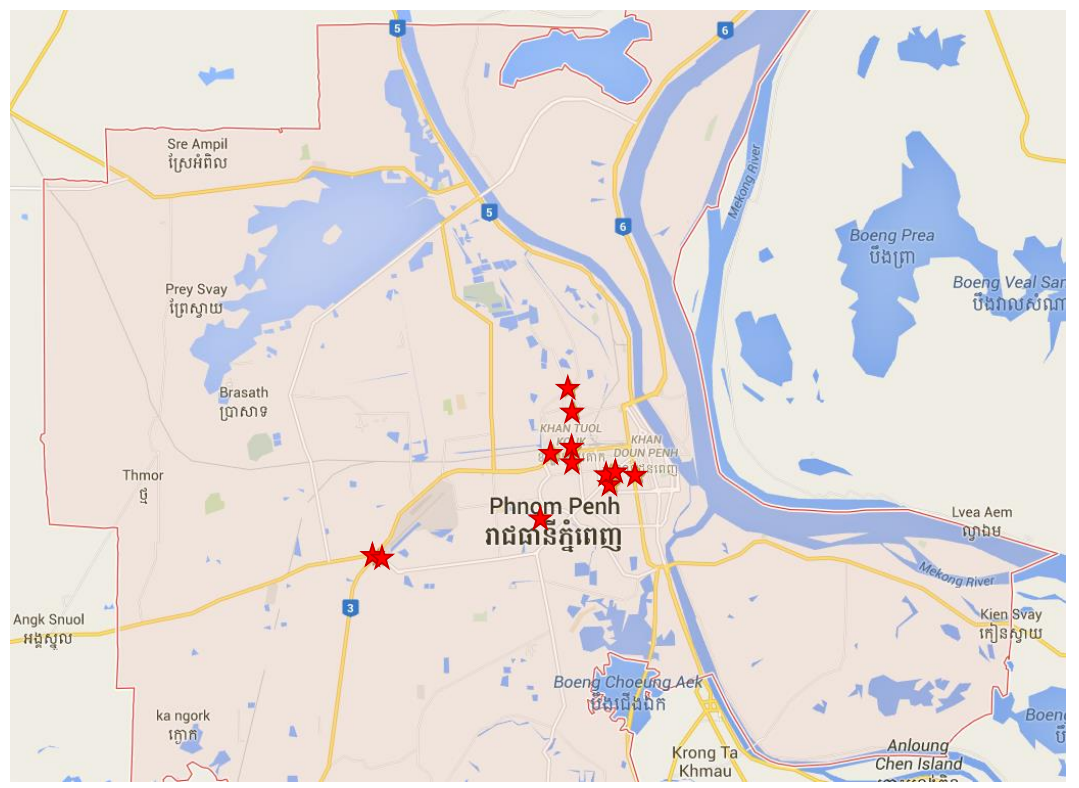

Fig. 2. Survey locations in Phnom Penh.

\section{Results}

\subsection{Descriptive Statistics}

Table 2 presents summary statistics of respondents' characteristics classifying by three travel modes, i.e. Motodup, Remork, and public bus. From the survey data, the distribution of male and female respondents is relatively equal for all three travel modes. The majority of respondents for Motodup, Remork and public bus are 19-25 years old, followed by those between 26-35 years old for Motodup, and less than or equal to 18 years old for Remork and public bus. Such a proportion of respondents is consistent with the statistics reported by the Central Intelligence Agency [14], as well as the previous research conducted in Phnom Penh [15].

In terms of occupation, students share the highest proportion $(64.7 \%, 67.1 \%$, and $75.7 \%$ for Motodup, Remork, and public bus, respectively). More than half of respondents reached university level, while $35.1 \%$, $34.6 \%$, and $32.4 \%$ of them using Motodup, Remork and public bus obtained only high school level or lower. A high percentage of respondents can be observed under the low income group, which earns less than or equal to 200 USD per month.

Survey indicates that $84.6 \%, 92.1 \%$ and $83.4 \%$ of respondents use Motodup, Remork and public bus occasionally respectively. Majority of passengers use all the three modes in the weekend with the share percentage of $66.4 \%$ for Motodup, $79.4 \%$ for Remork, and $66.4 \%$ for public bus. Approximately $49.4 \%$ of Motodup passengers uses it in the morning followed by $35.0 \%$ in the afternoon and $15.6 \%$ in the evening. Respondents using Remork in the morning hours shares the highest percentage (39.6\%), while the remaining $32.6 \%$ and $27.8 \%$ uses this mode in the afternoon and evening, respectively. On the other hand, the usage of public bus is highly distributed during the morning time (61.5\%).

Statistics shows that $20.1 \%$ of respondents use Motodup for education, $11.6 \%$ for work, $3.3 \%$ for business, $26.7 \%$ for shopping, and $38.3 \%$ for other purposes. With the same categories of trip purpose, $36.6 \%$ and $42.1 \%$ of Remork passengers use it for shopping other purposes, while using Remork for education, work and business share very small proportions. For public bus, 30.4\%, $11.3 \%, 1.6 \%, 10.1 \%$ and $46.6 \%$ use it for education, work, business, shopping, and others, respectively.

Table 3 presents respondents' trip characteristics in terms of travel time, travel cost, and distance. The average travel time per trip for Motodup and Remork is somewhat different (19.08 minutes and 24.54 minutes respectively), while that of public bus is relatively high (44.31 minutes). Motodup is basically more expensive 
than public bus but less costly than Remork. The average travel cost per trip for Motodup, Remork and public bus are reported to be $5800 \mathrm{KHR}, 10700 \mathrm{KHR}$, and $1100 \mathrm{KHR}$ (approximate $1.41 \mathrm{USD}, 2.60 \mathrm{USD}$, and 0.26 USD) respectively. However, public bus actually provides a fixed fare of $1500 \mathrm{KHR}(0.37 \mathrm{USD})$ for all stations with exemption for student, elderly, handicapped and monk. From our survey, 26.75\% of public bus passengers are zero-fare passengers, while $73.25 \%$ use public bus at fare $1500 \mathrm{KHR}$. Results from survey indicate that average travel distances per trip for Motodup is $4.74 \mathrm{Km}$, followed by Remork $(5.82 \mathrm{Km})$ and public bus $(6.38 \mathrm{Km})$.

Table 2. Descriptive statistics of respondents' characteristics.

\begin{tabular}{|c|c|c|c|c|}
\hline \multirow{2}{*}{ Variables } & \multirow{2}{*}{ Levels } & \multicolumn{3}{|c|}{ Percentage } \\
\hline & & Motodup & Remork & Public bus \\
\hline \multirow{2}{*}{ Gender } & Male & 50.6 & 44.9 & 49.8 \\
\hline & Female & 49.4 & 55.1 & 50.2 \\
\hline \multirow{5}{*}{ Age (years old) } & $\leq 18$ & 13.8 & 13.5 & 13.7 \\
\hline & $19-25$ & 61.7 & 71.3 & 76.4 \\
\hline & $26-35$ & 14.4 & 11.5 & 8.9 \\
\hline & $36-50$ & 6.6 & 3.3 & 0.5 \\
\hline & $\geq 51$ & 3.5 & 0.4 & 0.5 \\
\hline \multirow{5}{*}{ Occupation } & Student & 64.7 & 67.1 & 75.7 \\
\hline & Employee & 20.1 & 18.5 & 14.5 \\
\hline & Employer & 1.3 & 1.8 & 1.0 \\
\hline & Vendor & 7.5 & 7.0 & 4.5 \\
\hline & Others & 6.4 & 5.6 & 4.3 \\
\hline \multirow{3}{*}{ Education } & Below university & 35.1 & 34.6 & 32.4 \\
\hline & Undergraduate & 60.9 & 62.1 & 63.9 \\
\hline & Graduate & 4.0 & 3.3 & 3.7 \\
\hline \multirow{3}{*}{ Income } & Low & 81.4 & 77.8 & 85.2 \\
\hline & Medium & 13.0 & 15.9 & 12.2 \\
\hline & High & 5.6 & 6.3 & 2.6 \\
\hline \multirow[t]{4}{*}{ Frequency } & Occasionally & 86.4 & 92.1 & 83.4 \\
\hline & 2-3 times/week & 6.2 & 4.3 & 5.5 \\
\hline & 4-5 times/week & 2.8 & 1.1 & 2.2 \\
\hline & Everyday & 4.6 & 2.5 & 8.9 \\
\hline \multirow{2}{*}{ Day of week } & Weekdays & 33.6 & 20.6 & 33.6 \\
\hline & Weekends & 66.4 & 79.4 & 66.4 \\
\hline \multirow[t]{3}{*}{ Time of day } & Mornings & 49.4 & 39.6 & 61.5 \\
\hline & Afternoons & 35.0 & 32.6 & 30.0 \\
\hline & Evenings & 15.6 & 27.8 & 8.5 \\
\hline \multirow[t]{5}{*}{ Trip purpose } & Education & 20.1 & 8.4 & 30.4 \\
\hline & Work & 11.6 & 8.0 & 11.3 \\
\hline & Business & 3.3 & 4.9 & 1.6 \\
\hline & Shopping & 26.7 & 36.6 & 10.1 \\
\hline & Other & 38.3 & 42.1 & 46.6 \\
\hline
\end{tabular}

Note: levels of income per month per person are classified: low $\leq 200$ USD, Medium 201-500 USD, High $\geq 501$ USD. 
Table 3. Descriptive statistics of respondents' trip characteristics.

\begin{tabular}{|c|c|c|c|c|c|c|}
\hline Variables & Description & Mode $\left(m_{i}\right)$ & Mean & S.D. & Min & Max \\
\hline \multirow{3}{*}{$\begin{array}{l}\text { Travel } \\
\text { (Minute) }\end{array}$} & \multirow{3}{*}{ Average travel time per trip } & Motodup & 19.08 & 11.25 & 3 & 70 \\
\hline & & Remork & 24.54 & 13.52 & 5 & 80 \\
\hline & & Public bus & 44.31 & 37.44 & 5 & 150 \\
\hline \multirow{3}{*}{ Cost (KHR) } & \multirow{3}{*}{ Average travel cost per trip } & Motodup & 5800 & 3400 & 1500 & 20000 \\
\hline & & Remork $^{\#}$ & 10700 & 5400 & 3000 & 30000 \\
\hline & & Public bus* & 1100 & 600 & 0 & 1500 \\
\hline \multirow{3}{*}{ Distance $(\mathrm{Km})$} & \multirow{3}{*}{ Average travel distance per trip } & Motodup & 4.74 & 3.68 & 1 & 25 \\
\hline & & Remork & 5.82 & 4.64 & 1 & 20 \\
\hline & & Public bus & 6.38 & 3.89 & 0.2 & 15 \\
\hline
\end{tabular}

Note: 1 USD $=4100$ KHR (as of June 13, 2016).

\# Fare is per trip and there could be more than one person riding together in the same trip. ${ }^{*}$ Fare of public bus is fixed at $1500 \mathrm{KHR}$. Free rides for students, elderlies, the handicapped and monks.

Tables 4 summarizes the descriptive statistics of passengers' perception toward operational characteristics. In this questionnaire section, respondents were asked to use five-point Likert scale to rate the operational characteristics of three travel modes - Motodup, Remork and public bus. From the survey, the means that passengers agree with the statement "short travel time" are 3.70, 3.09 and 2.58 for Motodup, Remork, and public bus, respectively. In terms of coverage area, availability, and accessibility, Motodup and Remork's passengers agree that these two modes are available across the city, can be found anytime they need and can be found nearby. This corresponds with the rating mean of 3.99, 4.14, 4.19 for Motodup and 3.56, 3.64, 3.63 for Remork, while the means of the same rating statements are 2.73, 2.70 and 2.51 for public bus, respectively. Similarly, passengers show positive perception in terms of waiting time for Motodup and Remork (rating means 3.92 and 3.62 respectively), but not for public bus (rating mean 2.65).

In terms of comfort and vehicle condition, the results indicate that Motodup has below-average mean associated with comfort during traveling, vehicle cleanliness and the maintenance of vehicle material $(2.63$, 2.74, 2.65 respectively). With the same statements, rating means are 3.26, 3.20, 3.08 for Remork and 3.93, 3.85, 3.74 for public bus. Overall safety, on the other hand, is perceived positively from public bus's passengers, follow by Remork's and Motodup's with the rating means of 3.94, 3.21, and 2.65 respectively. Lastly, survey results associated with fare show that Motodup and Remork's passengers do not perceived that fare of these two modes low, but they do for public bus. This could be true since the average travel cost of Motodup, Remork and public bus are 5800 KHR, 10700 KHR and 1100 KHR respectively (See Table 3).

Table 4. Passengers' perception toward operational characteristics.

\begin{tabular}{|l|l|l|l|l|}
\hline \multirow{2}{*}{ Items } & \multirow{2}{*}{ Statement } & \multicolumn{3}{l|}{ Percentage } \\
\cline { 3 - 5 } & & Motodup & Remork & Public bus \\
\hline Q1 & "Short travel time" & $3.70(1.28)$ & $3.09(1.09)$ & $2.58(1.34)$ \\
\hline Q2 & "Operation is available across the city." & $3.99(1.25)$ & $3.56(1.18)$ & $2.73(1.36)$ \\
\hline Q3 & "Can be found anytime you need" & $4.14(1.18)$ & $3.64(1.14)$ & $2.70(1.44)$ \\
\hline Q4 & "Can be found nearby" & $4.19(1.12)$ & $3.63(1.18)$ & $2.51(1.37)$ \\
\hline Q5 & "Short waiting time" & $3.92(1.27)$ & $3.62(1.17)$ & $2.65(1.44)$ \\
\hline Q6 & "Seat is comfortable." & $2.63(1.21)$ & $3.26(1.15)$ & $3.93(1.24)$ \\
\hline Q7 & "Vehicle is clean" & $2.74(1.15)$ & $3.20(1.07)$ & $3.85(1.14)$ \\
\hline Q8 & "Interior material is well maintained." & $2.76(1.10)$ & $3.08(1.06)$ & $3.74(1.05)$ \\
\hline Q9 & "Overall safety is high." & $2.65(1.27)$ & $3.21(1.11)$ & $3.94(1.28)$ \\
\hline Q10 & "low fare" & $2.89(1.29)$ & $2.71(1.16)$ & $3.93(1.38)$ \\
\hline
\end{tabular}

Note: Figures in parentheses represent standard deviation. Five-point-scales are (1) strongly disagree, (2) disagree, (3) neutral, (4) agree, (5) strongly agree.

Respondents were also asked to choose and rank 3 out of 6 attributes that they consider important when they choose public transport modes. Out of 483 respondents, 336 choose convenience among which $43.75 \%$ ranks this attribute as the most important criteria when they decide to use public modes, while $31.55 \%$ and 
$24.70 \%$ ranks it as secondary and third importance respectively. On the other hand, a total of 313 respondents considers safety with distributed percentage of $66.45 \%$ for the most importance, $19.17 \%$ for secondary importance and $14.38 \%$ for third importance. Besides convenience and safety, travel time is the third most chosen attribute by passengers, followed by travel cost, availability and comfort. The detail of descriptive statistics of passengers' criteria when choosing public transport modes is presented in Table 5.

Table 5. Passengers' criteria when choosing public transport modes.

\begin{tabular}{|c|c|c|c|c|c|c|}
\hline & & Rank \#1 & Rank \#2 & Rank \#3 & Total & $\begin{array}{l}\% \% \text { compared to } \\
\text { total dataset }(483)\end{array}$ \\
\hline \multirow{2}{*}{ Convenience } & $\mathrm{N}$ & 147 & 106 & 83 & 336 & \multirow{2}{*}{$69.56 \%$} \\
\hline & $(\%)$ & $43.75 \%$ & $31.55 \%$ & $24.70 \%$ & $100.00 \%$ & \\
\hline \multirow{2}{*}{ Travel Time } & $\mathrm{N}$ & 63 & 115 & 83 & 261 & \multirow{2}{*}{$54.03 \%$} \\
\hline & $(\%)$ & $24.14 \%$ & $44.06 \%$ & $31.80 \%$ & $100.00 \%$ & \\
\hline \multirow{2}{*}{ Safety } & $\mathrm{N}$ & 208 & 60 & 45 & 313 & \multirow{2}{*}{$64.80 \%$} \\
\hline & $(\%)$ & $66.45 \%$ & $19.17 \%$ & $14.38 \%$ & $100.00 \%$ & \\
\hline \multirow{2}{*}{ Comfort } & $\mathrm{N}$ & 64 & 48 & 50 & 162 & \multirow{2}{*}{$33.54 \%$} \\
\hline & $(\%)$ & $39.51 \%$ & $29.63 \%$ & $30.86 \%$ & $100.00 \%$ & \\
\hline \multirow{2}{*}{ Travel Cost } & $\mathrm{N}$ & 60 & 95 & 101 & 256 & \multirow{2}{*}{$53.00 \%$} \\
\hline & $(\%)$ & $23.44 \%$ & $37.11 \%$ & $39.45 \%$ & $100.00 \%$ & \\
\hline \multirow{2}{*}{ Availability } & $\mathrm{N}$ & 69 & 91 & 79 & 239 & \multirow{2}{*}{$49.48 \%$} \\
\hline & $(\%)$ & $28.87 \%$ & $38.08 \%$ & $33.05 \%$ & $100.00 \%$ & \\
\hline
\end{tabular}

\subsection{Model Development}

\subsubsection{Model specification}

In transportation studies, discrete choice model is often utilized to examine the relationship among passengers' travel behavior, attributes of alternative and characteristics of individual passenger [16]. Data of discrete choice model could be presented in form of psychometric data, i.e. Stated Preference (SP) and subjective rating data, or Revealed Preference (RP) data [17]. In this study, revealed preference data of the frequency using Motodup, Remork and public bus has its nature outcome as ordinal category (1: Occasionally, 2: two-three days/week, 3: four-five days/week, 4: everyday). Under this case, ordered probit model is seen to be appropriate for the analysis, because multinomial logit fails to take the ordering of dependent variables into account, while regression model treats the difference between categories the same [18].

Dependent variable cannot be observed directly, and that is why latent variable is needed. The latent variable can be written as:

$$
y_{i}^{*}=\beta x_{i}+\varepsilon_{i}
$$

where,

$y_{i}^{*}$ : latent variable of frequency of using a mode by an individual $i$, coded as $1,2,3,4$

$x_{i}$ : the vector of independent variables of an individual $i$,

$\beta$ : the vector of parameters to be estimated, and

$\varepsilon_{i}$ : the error term, which is assumed to be normal distributed.

The values of $y_{i}$ fall between categories $j(j=1,2,3,4)$, and they are related with the linear function of $y_{i}^{*}$ such that $\mu_{j-1}<y_{i}^{*} \leq \mu_{j}$, where $\mu_{j}$ is known as threshold parameters or cutoff points. The relationship between $y_{i}, y_{i}^{*}$ and threshold points is shown in Eq. (2). 


$$
y_{i}=\left\{\begin{array}{lll}
1 \text { if } & -\infty<y_{i}^{*} \leq \mu_{1} & \text { (Use a mode occasionally) } \\
2 \text { if } & \mu_{1}<y_{i}^{*} \leq \mu_{2} & \text { (Use a mode 2-3 days/week) } \\
3 \text { if } & \mu_{2}<y_{i}^{*} \leq \mu_{3} & \text { (Use a mode 4-5 days/week) } \\
4 \text { if } & \mu_{3}<y_{i}^{*}<+\infty & \text { (Use a mode everyday) }
\end{array}\right.
$$

Like models in binary outcomes, concerns are stressed on how changes in the predictors translated into probabilities of observing a specific ordering outcome [19]. The probability that passengers use a mode in a particular outcome category is a standard normal cumulative function determined by threshold point $\mu_{j-1}$ and $\mu_{j}$. By knowing the function of latent variable $y_{i}^{*}$, the probability that individual $i$ uses a mode in any specific frequency category $j$ can be computed as follow:

$$
P_{i}\left(y_{i}=j\right)=P\left(\mu_{j-1}<y_{i}^{*} \leq \mu_{j}\right)=F\left(\mu_{j}-\beta x_{i}\right)-F\left(\mu_{j-1}-\beta x_{i}\right)
$$

According to a sample $\left(y_{i}, x_{i}, i=1, \ldots, n\right)$, the log-likelihood, which is a sum of each log probability can be written as in Eq. (4).

$$
\log L=\sum_{i=1}^{n} \log \left[P_{i}\left(y_{i}=j\right)\right], \quad j=\{1,2,3,4\}
$$

\section{Marginal Effects}

Marginal effect expresses the change of dependent variable when independent variable changes. Regarding to the application of ordered probit model in this study, the marginal effect can be interpreted as the probability that passengers are more or less likely to use a mode in ordinal categories. It has been known that probit model is assumed to be normal distributed, and thus

$$
\operatorname{Pr}(y=j)=\int_{\infty}^{x} \frac{1}{\sqrt{2 \pi}} e^{\frac{-x^{2}}{2}} d x
$$

The marginal effects of continuous variable $x_{k}$ is given by:

$$
\frac{\partial \operatorname{Pr}(y=j)}{\partial x_{k}}=F(\beta x) \beta_{k}, \quad j=\{1,2,3,4\}
$$

Where,

$F(\beta x)$ is the standard normal density function determined by $\beta x$, so $F(\beta x)=\frac{1}{\sqrt{2 \pi}} e^{\frac{-(\beta x)^{2}}{2}}$

Measure of Fit

Likelihood ratio index is used to measure the goodness-of-fit of the model based on the value of loglikelihood [20]. The index is represented by $\rho^{2}$, and defined as:

$$
\rho^{2}=1-\left(\frac{\log L\left(\beta_{\text {initial }}\right)}{\log L\left(\beta_{\text {convergence }}\right)}\right)
$$


where,

$\log L\left(\beta_{\text {initial }}\right)$ is the $\log$-likelihood at zero iteration where model has only constant term (i.e., vector of coefficients is set to zero);

$\log L\left(\beta_{\text {convergence }}\right)$ is the $\log$-likelihood value at convergence.

The value of $\rho^{2}$ ranges between zero and one. The $\rho^{2}$ is equal to zero when all coefficients in the model are equal to zero, but will be close to one when the goodness-of-fit is improved. The value of $\rho^{2}$ can be described as the percentage that the model can explain more compared to the null model. There is also another similar measurement of goodness-of-fit that corrects for all number of estimated parameters. In this measurement, degree of freedom or number of parameters in model $\mathrm{K}$ also take into account [21]. Also see [22] for more discussion on goodness-of-fit. The equation can be written as:

$$
\rho_{\text {adjusted }}^{2}=1-\left(\frac{\log L\left(\beta_{\text {initial }}-K\right)}{\log L\left(\beta_{\text {convergence }}\right)}\right)
$$

\subsubsection{Model estimation results}

Table 6 presents model estimation results. Four sets of explanatory variables, including socio-economic variables, trip characteristics, passenger's perception toward operational characteristics, and passenger's criteria in choosing public transport, are tested in modeling process. It can be observed that they all have an impact on models of Motodup and Remork. Nevertheless, a set of passengers' perceptions toward operational characteristics does not found to be significant in public bus's model. Many of explanatory variables are statistically significant at either $95 \%$ or $90 \%$ confidence level. The goodness-of-fit of the models in terms of $\rho^{2}$ are $0.1150,0.4224$ and 0.4016 for Motodup, Remork, and public bus, respectively. Since the dependent variable has four ordinal category outcomes, there are three threshold points. The threshold points of each model are statistically significant at $95 \%$ confidence level. This could be implied that the four categorical outcomes should not be combined into one.

Modeling results for Motodup reveal that two dummy variables of student and employee, and travel cost carry negative coefficients. This simply means that passengers who are students or employee are less likely to use Motodup frequently. Likewise, the increase in travel cost results in decreasing the likelihood of using Motodup. On the other hand, five explanatory variables have positive impacts on the frequency of usage.

The dependent variable for Remork is determined by eleven explanatory variables. It can be seen that students have positive impact on Remork's model, but this dummy variable has negative coefficient in Motodup's model. This could be implied that students prefer Remork than Motodup.

Educational level and travel cost are the two factors that have negative impact on the frequency of using public bus once their values increase. Travel distance is found to have positive coefficient, implying that the longer the travel distance, the more frequent public bus would be used. This could be the case because the public bus provides passengers with low fare compared to Motodup and Remork. Fare of public bus is set to be $1500 \mathrm{KHR}(0.37 \mathrm{USD})$ for all stations, while the average travel cost of Motodup and Remork is reported to be $5800 \mathrm{KHR}$ (1.42 USD) and 10,700 KHR (2.62 USD), respectively [23]. Since the fare does not linearly increase with the travel distance, it is not surprising that passengers would prefer public bus due to the large difference in travel cost.

\subsubsection{Marginal effects and predicted probabilities}

Unlike the linear regression where marginal effects can be interpreted directly from coefficients of regressors, marginal effects in ordered probit models are measured as the probabilities associated with the likelihood of using Motodup/Remork/public bus in each frequency category. Table 7 presents the marginal effects of frequency using the three public transport modes.

From the results, absolute values of marginal effects decrease from the least frequent category to the most frequent category for all the three modes. It can be implied that passengers mainly use Motodup/Remork/public bus occasionally only. This could be justified since most travelers have already owned their private vehicle, mainly a motorcycle. Another reason may be a matter of travel cost. Travel cost 
of Motodup and Remork is considered expensive compared to public bus fare [23] that travelers cannot afford them for commuting on a daily basis. However, the public bus service quality is still limited, leading to a long travel time [4]. Due to this reason, public bus would not be the chosen choice by commuters for their daily trip.

Table 6. Model estimation results.

\begin{tabular}{|c|c|c|c|c|c|c|}
\hline Variable & Coef. & Std. Err. & t-stat. & p-value & \multicolumn{2}{|c|}{ Model's Statistics } \\
\hline \multicolumn{7}{|l|}{ Motodup } \\
\hline Student & $-1.0582^{* *}$ & 0.2630 & -4.02 & 0.000 & \multirow{10}{*}{$\begin{array}{l}\mathrm{N} \\
\mathrm{LR} \chi^{2}[7] \\
\mathrm{p}>\chi^{2} \\
\text { Pseudo } \mathrm{R}^{2} \\
\text { Log Likelihood }\end{array}$} & \multirow{10}{*}{$\begin{array}{l}=274 \\
=34.22 \\
=0.000 \\
=0.1150 \\
=-131.63\end{array}$} \\
\hline Employee & $-0.7402^{* *}$ & 0.3070 & -2.41 & 0.016 & & \\
\hline Medium income & 0.4672 & 0.2871 & 1.63 & 0.104 & & \\
\hline Cost (100 KHR) & $-0.0055^{*}$ & 0.0030 & -1.79 & 0.074 & & \\
\hline Q6 & $0.1556^{*}$ & 0.0828 & 1.88 & 0.060 & & \\
\hline Convenience & $0.1994 *$ & 0.0751 & 2.01 & 0.045 & & \\
\hline Comfort & $0.1537^{*}$ & 0.0993 & 1.71 & 0.087 & & \\
\hline -Cut 1 & $0.9164^{* *}$ & 0.3883 & 2.36 & & & \\
\hline -Cut 2 & $1.2114^{* *}$ & 0.3922 & 3.08 & & & \\
\hline -Cut 3 & $1.5365^{* *}$ & 0.3992 & 3.84 & & & \\
\hline \multicolumn{7}{|l|}{ Remork } \\
\hline Female & $-1.0555^{* *}$ & 0.4099 & -2.57 & 0.010 & \multirow{14}{*}{$\begin{array}{l}\text { N } \\
\text { LR } \chi^{2}[11] \\
\mathrm{p}>\chi^{2} \\
\text { Pseudo } \mathrm{R}^{2} \\
\text { Log Likelihood }\end{array}$} & \multirow{14}{*}{$\begin{array}{l}=232 \\
=67.72 \\
=0.000 \\
=0.4224 \\
=-46.30\end{array}$} \\
\hline Student & $1.2773^{* *}$ & 0.5815 & 2.20 & 0.028 & & \\
\hline Education level & $-0.2942^{* *}$ & 0.1252 & -2.35 & 0.019 & & \\
\hline Weekday & $1.3043^{* *}$ & 0.3978 & 3.28 & 0.001 & & \\
\hline Morning & $1.0766^{* *}$ & 0.4018 & 2.68 & 0.007 & & \\
\hline Evening & $0.9632^{* *}$ & 0.3945 & 2.44 & 0.015 & & \\
\hline For business & $2.0633^{* *}$ & 0.6184 & 3.34 & 0.001 & & \\
\hline Q2 & $0.2678^{*}$ & 0.1608 & 1.67 & 0.096 & & \\
\hline Q3 & $0.5711 * *$ & 0.2300 & 2.48 & 0.013 & & \\
\hline Comfort & 0.2400 & 0.1634 & 1.47 & 0.142 & & \\
\hline Availability & $0.2923^{*}$ & 0.1585 & 1.84 & 0.065 & & \\
\hline -Cut 1 & $6.7377 * *$ & 1.7116 & 3.93 & & & \\
\hline -Cut 2 & $7.5121^{* *}$ & 1.7436 & 4.30 & & & \\
\hline -Cut 3 & $7.7661^{* *}$ & 1.7517 & 4.43 & & & \\
\hline \multicolumn{7}{|l|}{ Public bus } \\
\hline High school & $0.8881^{*}$ & 0.4584 & 1.94 & 0.053 & \multirow{10}{*}{$\begin{array}{l}\mathrm{N} \\
\mathrm{LR} \chi^{2}[7] \\
\mathrm{p}>\chi^{2} \\
\text { Pseudo } \mathrm{R}^{2} \\
\text { Log Likelihood }\end{array}$} & \multirow{10}{*}{$\begin{array}{l}=95 \\
=54.88 \\
=0.000 \\
=0.4016 \\
=-40.88\end{array}$} \\
\hline Education level & -0.4058 & 0.2473 & -1.64 & 0.101 & & \\
\hline Weekday & $2.8346^{* *}$ & 0.7498 & 3.78 & 0.000 & & \\
\hline Cost (100 KHR) & $-0.1218^{* *}$ & 0.0320 & -3.80 & 0.000 & & \\
\hline Distance & $0.1116^{* *}$ & 0.0546 & 2.04 & 0.041 & & \\
\hline Comfort & $0.6185^{* *}$ & 0.2625 & 2.36 & 0.018 & & \\
\hline Availability & $0.4620^{* *}$ & 0.2099 & 2.20 & 0.028 & & \\
\hline -Cut 1 & $2.3312^{* *}$ & 1.0771 & 2.16 & & & \\
\hline -Cut 2 & $2.6275^{* *}$ & 1.0838 & 2.42 & & & \\
\hline -Cut 3 & $2.9153^{* *}$ & 1.0961 & 2.65 & & & \\
\hline
\end{tabular}

Note: ${ }^{*} p<0.1,{ }^{*} p<0.05$. Variables Q2, Q3, and Q6 refer to perception toward operational characteristics described in Table 4. Socioeconomic variables are modeled as dummy variables. 
Table 7. Marginal effects of frequency using public transport modes.

\begin{tabular}{|c|c|c|c|c|}
\hline \multirow{2}{*}{ Variables } & \multicolumn{4}{|c|}{ Frequency } \\
\hline & Occasionally & 2-3 days/week & 4-5 days/week & Everyday \\
\hline \multicolumn{5}{|c|}{ Motodup } \\
\hline Student & $0.2433^{* *}$ & $-0.0672 * *$ & $-0.0636^{* *}$ & $-0.1125^{* *}$ \\
\hline Employee & $0.0988^{* *}$ & $-0.0367 * *$ & $-0.0283^{* *}$ & $-0.0338 * *$ \\
\hline Medium income & -0.1043 & 0.0312 & 0.0283 & 0.0448 \\
\hline Cost (100 KHR) & $0.00099 *$ & -0.00033 & -0.00028 & $-0.00038^{*}$ \\
\hline Q6 & $-0.0281 *$ & $0.0095 *$ & $0.0079 *$ & $0.0107 *$ \\
\hline Convenience & $-0.0361 * *$ & $0.0122^{*}$ & $0.0102 *$ & $0.0137 *$ \\
\hline Comfort & $-0.0278^{*}$ & 0.0094 & 0.0078 & 0.0106 \\
\hline \multicolumn{5}{|c|}{ Remork } \\
\hline Female & 0.0121 & -0.0109 & -0.0007 & -0.0005 \\
\hline Student & -0.0075 & 0.0069 & 0.0004 & 0.0002 \\
\hline Educational level & 0.0027 & -0.0025 & -0.0001 & -0.0001 \\
\hline Weekday & -0.0432 & 0.0367 & 0.0034 & 0.0031 \\
\hline Morning & -0.0160 & 0.0143 & 0.0010 & 0.0007 \\
\hline Evening & -0.0167 & 0.0148 & 0.0011 & 0.0008 \\
\hline Business purpose & -0.2207 & 0.1587 & 0.0254 & 0.0366 \\
\hline Q2 & -0.0025 & 0.0023 & 0.0001 & 0.0001 \\
\hline Q3 & -0.0054 & 0.0050 & 0.0002 & 0.0002 \\
\hline Comfort & -0.0023 & 0.0021 & 0.0001 & 0.0001 \\
\hline Availability & -0.0027 & 0.0025 & 0.0001 & 0.0001 \\
\hline \multicolumn{5}{|c|}{ Public bus } \\
\hline Educational level & 0.0302 & -0.0134 & -0.0081 & -0.0087 \\
\hline High school & -0.0905 & 0.0362 & 0.0237 & 0.0306 \\
\hline weekday & $-0.3123^{* *}$ & $0.0960 * *$ & $0.0745^{*}$ & $0.1418^{* *}$ \\
\hline Cost (100 KHR) & 0.0090 & -0.0040 & -0.0024 & -0.0026 \\
\hline Distance & -0.0082 & 0.0036 & 0.0022 & 0.0024 \\
\hline Comfort & -0.0461 & 0.0205 & 0.0123 & 0.0133 \\
\hline Availability & -0.0344 & 0.0153 & 0.0092 & 0.0099 \\
\hline
\end{tabular}

Note: ${ }^{*} p<0.1{ }^{* *} p<0.05$.

Table 8 compares the mean of predicted probabilities and the actual distribution of frequency using Motodup, Remork, and public bus. The results show that the mean values of predicated probabilities are relatively close to the actual data. This reflects the good performance of the model in predicting the frequency of using Motodup, Remork, and public bus.

Table 8. Comparison between predicted probabilities and actual data.

\begin{tabular}{|l|c|c|c|c|c|c|}
\hline \multirow{2}{*}{ Frequency } & \multicolumn{2}{|c|}{ Motodup } & \multicolumn{2}{c|}{ Remork } & \multicolumn{2}{c|}{ Public bus } \\
\cline { 2 - 7 } & $\begin{array}{c}\text { Mean of } \\
\text { predicted } \\
\text { probabilities }\end{array}$ & Actual data & $\begin{array}{c}\text { Mean of } \\
\text { predicted } \\
\text { probabilities }\end{array}$ & Actual data & $\begin{array}{c}\text { Mean of } \\
\text { predicted } \\
\text { probabilities }\end{array}$ & Actual data \\
\hline Occasionally & 86.57 & 86.38 & 92.37 & 92.11 & 76.94 & 83.47 \\
\hline 2-3 days/week & 4.68 & 6.17 & 4.22 & 4.30 & 4.10 & 5.51 \\
\hline 4-5 days/week & 3.58 & 2.83 & 0.81 & 1.08 & 3.56 & 2.12 \\
\hline Everyday & 5.15 & 4.63 & 2.58 & 2.51 & 15.38 & 8.90 \\
\hline
\end{tabular}




\section{Discussion and Conclusion}

The present study investigates factors influencing the frequency using informal transport (i.e. Motodup and Remork) and public bus in Phnom Penh. Statistical models are developed based on four sets of explanatory variables. Results indicate that these four sets of variables have certain impacts on frequency of using Motodup and Remork. However, passengers' perception toward operational characteristics of public bus does not have the effect on model itself.

Motodup and Remork have been regarded as the conventional modes in urban area of Phnom Penh for decades. Findings from this study demonstrate significant factors affecting the frequency of using them. These factors could be used to improve their service quality, although currently there is no official authority in control of the operation. From the modeling results, travel cost has an effect in reducing frequency of using Motodup; therefore, the fare should start with one reasonable minimum price, and the entire travel cost should base on travel distance. This could make charging system become more regulated.

Public bus, on the other hand, is currently a highly promoted travel mode. To increase the passengers' frequency in using public bus, certain important factors should be considered. What could be done should be the improvement of service attributes (i.e. comfort and availability) and the extension of service routes given that the fare should not linearly increase with service length. The newly introduced public bus's service seems to be new for local commuters, and the subsidy from the government plays an essential role to support the operation. Findings also indicate that students in high school would use public bus more frequently than other types of passengers. The usage in weekday is strongly associated with this pattern. Thus, policy makers and transit operators could directly target young adults. In addition, the operation during weekday may need to be increased.

Although Phnom Penh is suffering from traffic congestion, and informal transport and public bus are the only public transport available in the city, they are not used on a daily basis. Local people are quite familiar with Motodup and Remork, but travel cost is typically higher than the ability to pay for daily commute. On the contrary, public bus provide a reasonable fare but the current service quality may not be up to passenger's expectation.

Although the present study provides some insights into the factors that influence the frequency of using informal transport and public bus, findings are still far from definite. Future studies may consider additional explanatory variables in the models (i.e. passengers' experience in using each mode, passengers' accessibility) so that models can describe passengers' travel behavior in wider details. Additionally, the application of technology should also assist transport planners to regulate the operation of both informal transport and public bus (i.e. fare charge, seeking for nearby public transport). In principle, informal transport and public bus should be harmonized in order to make a better connection in transport network, and this would create a sustainable urban transport for the city.

\section{Acknowledgements}

Authors would like to convey gratitude to AUN/SEED-Net for an opportunity to conduct this research as well as for the financial support. Also, we would like to thank senior students from the Institute of Technology of Cambodia for their assistance in data collection in Phnom Penh.

\section{References}

[1] V. K. Phun and T. Yai, "State of the art of paratransit literatures in Asian developing countries," in Proceeding of the Eastern Asia Society for Transport Studies, 2016, pp. 57-77.

[2] A. Tangphaisankun, F. Nakamura, and T. Okamura, "Influences of paratransit as a feeder of mass transit system in developing countries based on commuter satisfaction," in Proceedings of the Eastern Asia Society for Transportation Studies 2009, pp. 236-236.

[3] V. K. Phun, I. Lim, and T. Yai, "The characteristics of paratransit operation and fare in Phnom Penh," Journal of the Eastern Asia Society for Transportation Studies, vol. 11, pp. 1307-1327, 2015.

[4] V. K. Phun, P. Pheng, and T. Yai, "Using ordered probit modeling to assess perceived bus performance in Phnom Penh," Journal of the Eastern Asia Society for Transportation Studies, vol. 11, pp. 1155-1172, 2015.

[5] R. Cervero, "Informal transport in the developing world," UN-HABITAT, 2000. 
[6] T. B. Joewono and H. Kubota, "User satisfaction with paratransit in competition with motorization in indonesia: Anticipation of future implications," Transportation, vol. 34, no. 3, pp. 337-354, 2007.

[7] R. Cervero and A. Golub, "Informal transport: A global perspective," Transport Policy, vol. 14, no. 6, pp. 445-457, 2007.

[8] K. Etherington and D. Simon, "Paratransit and employment in Phnom Penh: The dynamics and development potential of cyclo riding," Journal of transport geography, vol. 4, no. 1, pp. 37-53, 1996.

[9] T. B. Joewono and H. Kubota, "The characteristics of paratransit and non-motorized transport in Bandung, Indonesia," Journal of the Eastern Asia Society for Transportation Studies, vol. 6, pp. 262-277, 2005.

[10] B. P. Loo, "The role of paratransit: some reflections based on the experience of residents' coach services in Hong Kong," Transportation, vol. 34, no. 4, pp. 471-486, 2007.

[11] K. Choocharukul and K. Sriroongvikrai, "Service characteristics of informal pubic transport: A case of Bangkok's small-sized converted pickup trucks," in Proceedings of the Eastern Asia Society for Transportation Studies, 2011, pp. 188-188.

[12] M. Hossain and Y. Susilo, "Rickshaw use and social impacts in Dhaka, Bangladesh," Transportation Research Record: Journal of the Transportation Research Board, no. 2239, pp. 74-83, 2011.

[13] V. A. Tuan and I. B. Mateo-Babiano, "Motorcycle taxi service in Vietnam-Its socioeconomic impacts and policy considerations," Journal of the Eastern Asia Society for Transportation Studies, vol. 10, pp. 13-28, 2013.

[14] CIA: Central Intelligence Agency. The World Fact Book [Online]. Available: https://www.cia.gov/library/publications/resources/the-world-factbook/geos/cb.html. [Accessed: 11 February 2016]

[15] B. Long, K. Choocharukul, and T. Nakatsuji, "Psychological factors influencing behavioral intention toward future sky train usage in Phnom Penh, Cambodia," Transportation Research Record: Journal of the Transportation Research Board, no. 2217, pp. 63-70, 2011.

[16] M. Ben-Akiva and B. Boccara, "Discrete choice models with latent choice sets," International Journal of Research in Marketing, vol. 12, no. 1, pp. 9-24, 1995.

[17] T. Morikawa, M. Ben-Akiva, and D. McFadden, "Discrete choice models incorporating revealed preferences and psychometric data," in Advances in Econometrics. Emerald Group Publishing Limited, 2002, pp. 29-55.

[18] M. A. Abdel-Aty, "Using ordered probit modeling to study the effect of ATIS on transit ridership," Transportation Research Part C: Emerging Technologies, vol. 9, no. 4, pp. 265-277, 2001.

[19] S. Jackman, "Models for ordered outcomes," Political Science C, vol. 200, pp. 1-20, 2000.

[20] K. Jang, S. H. Park, S. Chung, and K. H. Song, "Influential factors on level of injury in pedestrian crashes: Applications of ordered probit model with robust standard errors," Safe Transportation Research \& Education Center, 2010.

[21] C. Duncan, A. Khattak, and F. Council, "Applying the ordered probit model to injury severity in truckpassenger car rear-end collisions," Transportation Research Record: Journal of the Transportation Research Board, no. 1635, pp. 63-71, 1998.

[22] C. O'donnell and D. Connor, "Predicting the severity of motor vehicle accident injuries using models of ordered multiple choice," Accident Analysis \& Prevention, vol. 28, no. 6, pp. 739-753, 1996.

[23] N. Eung and K. Choocharukul, "Travel behavior of paratransit and city bus passengers in Phnom Penh," in Proceedings of the 21st National Convention on Civil Engineering, Songkhla, Thailand, 2016. 